\section{NLRP12 gene mutation in India: case finding and diagnosis made easy in the days of whole exome sequencing}

I read with interest the paper 'Novel NLRP12 variant presenting with familial cold autoimmunity syndrome phenotype' by Gupta et al in one of the issues in your esteemed journal. ${ }^{1}$ We have reported another patient with a different site of mutation in the same gene from another part of India earlier this year. ${ }^{2}$

Compared with the patient under discussion our patient had a milder phenotype in the form of recurrent fever, abdominal pain, nausea and vomiting lasting for 4-5 days every month along with mood changes and severe loss of appetite. He started his problem much later, that is, at the age of 9 years, and did not have classical skin and joint symptoms but had hypermobility of the joints. Our patient had a mutation of NLRP12 gene in exon 3 (c 779C > T, p Thr260 > Meth) in the evolutionarily conserved NACHT1 domain of the molecule in contrast to the case reported in the journal where the mutation was in LRR that is, leucinerich repeat domain of the molecule in the exon 9 of the NLRP12 gene (c.54299276T>C:r.2935a>g:p.Ser979Gly). In both the cases, an alpha hydroxy(active) amino acid is replaced by another amino acid. Glycine in the present case is a neutral amino acid with no spare active radical but $\mathrm{SH}$ radical of methionine is not too distant from the hydroxyl radical of threonine. This might have conserved some of the function of the molecule in our case. Neither the mutation described by present case and in our case has been described elsewhere, but mutations (base change) in the similar areas of the gene has been reported. ${ }^{34}$ Mood changes in our patient lead to further investigations to exclude porphyria. In both cases, exome analysis along with clinical presentation suggested the diagnosis and Sanger sequencing proved the diagnosis. In our case, none of the asymptomatic parents as well as asymptomatic elder brother of the patient showed the mutation suggesting a new mutation in the proband. The milder disease in our patient can also be due to heteryzygous mutation, whereas the patient described in this journal had homozygous mutation. Most of the patient reported in the literature ${ }^{3-5}$ has haploinsufficiency of the gene; from that standpoint the homozygous mutation reported here is important, but this begs the question why none of the parents have any symptoms of the disease. In a multidomain multifunctional protein, it is extremely important which domain is affected by mutation, and that could be one reason why so much heterogeneity of presentation in this disease has been reported. Our patient was reasonably well controlled with short course of naproxen and steroids during his attacks. Environment may have played some role in variable presentation of this disease in addition to genetic and epigenetic reasons and interactions. Our patient lived in a place where temperature rarely goes down below $25^{\circ} \mathrm{C}$ whereas the patient presented in this paper might have faced ambient temperature nearing $3-4^{\circ} \mathrm{C}$ for many days in long winter months of north India. Finally, in a country of 1.37 billion, it is but natural that we will continue to see such cases, and diagnosis may be clinched where whole exome and Sanger sequencing is being increasingly available.

\section{Kanjaksha Ghosh ${ }^{\oplus 1,2}$}

${ }^{1}$ Immunology, National Institute of Immunohematology, Mumbai, India

${ }^{2}$ Transfusion Medicine, Surat Raktadan Kendra and Research Centre, Surat, India

Correspondence to Professor Kanjaksha Ghosh, Immunology, National Institute of Immunohematology, Mumbai, Maharashtra 400012, India;

kanjakshaghosh@hotmail.com

Handling editor Josef S Smolen

Contributors I have some thought, written and made the sole contribution for this correspondence.

Funding The authors have not declared a specific grant for this research from any funding agency in the public, commercial or not-for-profit sectors.

Competing interests None declared.

Patient consent for publication Not required.

Provenance and peer review Not commissioned; internally peer reviewed.

(c) Author(s) (or their employer(s)) 2019. No commercial re-use. See rights and permissions. Published by BMJ.

\section{A) Check for updates}

To cite Ghosh K. Ann Rheum Dis Epub ahead of print: [please include Day Month Year]. doi:10.1136/annrheumdis-2019-216270

Received 5 September 2019

Accepted 8 September 2019

\section{S Linked}

http://dx.doi.org/10.1136/annrheumdis-2019-216158

Ann Rheum Dis 2019;0:1. doi:10.1136/annrheumdis-2019-216270

\section{REFERENCES}

1 Gupta L, Ahmed S, Singh B, et al. Novel NLRP12 variant presenting with familial cold autoimmunity syndrome phenotype. Ann Rheum Dis 2019. doi:10.1136/ annrheumdis-2019-216158. [Epub ahead of print: 24 Aug 2019].

2 Ghosh K, Mishra K, Shah A, et al. Novel deleterious sequence change in the NLRP12 gene in a child with the autoinflammatory syndrome, joint hypermobility and cutis laxa from India. Mediterr J Hematol Infect Dis 2019;11:e2019018. eCollection 2019.

3 Kostik MM, Suspitsin EN, Guseva MN, et al. Multigene sequencing reveals heterogeneity of NLRP12 related autoinflammatory disorders. Rheum Internat 2018.

4 Vitale A, Rigante D, Maggio MC, et al. Rare NLRP12 variants associated with the NLRP12-autoinflammatory disorder phenotype: an Italian case series. Clin Exp Rheumatol 2013;31(3 Suppl 77):155-6.

5 Jéru I, Duquesnoy P, Fernandes-Alnemri T, et al. Mutations in NALP12 cause hereditary periodic fever syndromes. Proc Natl Acad Sci U SA 2008;105:1614-9. 